\title{
Preservation of Encysted Polytomella
}

\author{
By RICHARD B. REED, FRANK P. SIMIONE, JR, AND \\ MARIAN S. MCGRATH
}

American Type Culture Collection, I230 I Parklawn Drive, Rockville, Maryland 20852, U.S.A.

(Received I8 November 1975; revised I April 1976)

SUMMARY

Cysts of Polytomella parva and Polytomella caeca were recovered after 7 days storage at cryogenic temperatures following drying on shredded filter paper, silica gel or without added substrate. Accelerated storage testing, by exposing dried material to elevated temperatures, indicated that shredded filter paper was the best of the substrates tested. Polytomella parva was recovered after 5 years storage at $-30{ }^{\circ} \mathrm{C}$ when dried on filter paper but not when dried on silic agel. Determinations of the number of cysts recovered indicated that viable cysts survived all conditions of storage tested. However, excystment following storage was delayed, the extent depending on storage conditions and the substrate used for drying. Most rapid recovery occurred when cysts were rehydrated immediately after drying, and after storage on filter paper at below $-70^{\circ} \mathrm{C}$.

\section{INTRODUCTION}

Preservation of cysts affords a means of long-term storage of free-living protozoons (Corliss \& Esser, 1974), especially when preservation of the vegetative form is complicated or completely unsuccessful. Cysts vary in their ability to resist environmental extremes. Ultra-low temperatures, or extremely dry conditions, favour the recovery of viable cultures following long-term storage of micro-organisms (Burns, 1964); and exposure of cysts to cryogenic temperatures must be preceded by proper conditioning. Dawson \& Hewett (I93I) demonstrated that cysts of Colpoda cucullus remain viable for more than 5 years in the dried state. The ciliates Didinium (Beers, 1937) and Euplotes (Garnjobst, 1937), however, do not survive drying in the encysted state. Dried Colpoda cysts are resistant to temperature extremes (Taylor \& Strickland, 1935, 1936), and can survive freezing and thawing (Bychenkova, Lozina-Lozinsky \& Namalov, I969). Simon \& Schneller (1973) reported the recovery of the ciliate Cyrtilophosis mucicola following exposure of dried cysts to - $196{ }^{\circ} \mathrm{C}$.

Attempts to preserve the vegetative cells of the free-living flagellate Polytomella by freezing or freeze-drying have repeatedly been unsuccessful (Burns, I964; Reed \& Simione, unpublished data). We have therefore investigated the preservation of Polytomella dried in the encysted state. The stability of the preserved material was tested by an accelerated storage test developed by Greiff \& Rightsel (I965) for dried viral suspensions, and also used on dried bacterial preparations (Damjanovic \& Radulovic, I968; Mitic, Damjanovic \& Otenhajmer, I969; Mitic, Otenhajmer \& Damjanovic, 1974). 


\section{METHODS}

Preparation of vials. Whatman filter paper no. 5 was cut into strips, shredded in a Waring blender in the presence of distilled water until a pulpy consistency was attained, and drained on absorbent paper, but was not allowed to dry completely. A small amount of the moist filter paper was loosely placed on the bottom of I $\times 35 \mathrm{~mm}$ freeze-drying shell vials (VWR Scientific no. 2792I-015; 660 Amberton Drive, Baltimore, Maryland 2I 227, U.S.A.) to a depth of 2.0 to $5.0 \mathrm{~mm}$. Silica gel (Fisher Scientific Co., 6 to 12 mesh, grade 40), ground to a fine powder with a mortar and pestle, was placed in a second group of shell vials so that it just covered the bottom of each one. A third group of vials was prepared without filter paper or silica gel. All vials were cotton-plugged, autoclaved for $30 \mathrm{~min}$ at $12 \mathrm{I}{ }^{\circ} \mathrm{C}$, and allowed to remain at room temperature for a minimum of $48 \mathrm{~h}$ before use.

Culture conditions and drying. Polytomella parva ATCCI 2910 and $P$. caeca ATCC30295 were cultured at $25^{\circ} \mathrm{C}$ under 16 I4 lux of light on ATCC medium 35I (Alexander, 1976) supplemented with $0.1 \% \mathrm{CH}_{3} \mathrm{COONa} \cdot 3 \mathrm{H}_{2} \mathrm{O}$. Cultures, grown for 7 days in $\mathrm{I} 00 \mathrm{ml}$ loosely capped bottles containing $25 \mathrm{ml}$ medium, were harvested by centrifuging at $200 \mathrm{~g}$ for $5 \mathrm{~min}$, and resuspended in the supernatant to give approximately $10 \times 10^{6}$ vegetative cells $\mathrm{ml}^{-1}$. Portions $(0.3 \mathrm{ml})$ were dispensed into the prepared vials and held at $25{ }^{\circ} \mathrm{C}$ for 14 days.

Preservation and storage. After I4 days drying, some vials were plunged directly into liquid nitrogen for $5 \mathrm{~min}$ and then stored for 7 days in the vapour phase $\left(-150^{\circ} \mathrm{C}\right)$ of a liquid-nitrogen refrigerator. The remaining vials were placed in $\mathrm{I} 4 \times 85 \mathrm{~mm}$ outer shell vials (VWR Scientific no. 2792 I-OI5) containing approximately $0.1 \mathrm{~g}$ silica gel, hermetically sealed under $0.67 \mathrm{~Pa}$ ( 5 mTorr) vacuum, and stored for 7 days at $4,-30$ or $-70{ }^{\circ} \mathrm{C}$. Control ampoules in each group were rehydrated immediately after drying.

Accelerated storage test. Vials stored at $4{ }^{\circ} \mathrm{C}$ were exposed for $30 \mathrm{~min}$ either to room temperature, to 35 or $60^{\circ} \mathrm{C}$ in a water bath, or to $100{ }^{\circ} \mathrm{C}$ by placing them directly into boiling water, and were then immediately rehydrated.

Rehydration. Growth medium $(0.5 \mathrm{ml})$ was added to each vial, which was then incubated at $25{ }^{\circ} \mathrm{C}$ in the dark (the amount of medium being maintained at $0.5 \mathrm{ml}$ ). The vials were examined daily and when numerous motile cells were evident ( 24 to $48 \mathrm{~h}$ after the appearance of flagellates) the liquid contents of the vials were transferred to $5.0 \mathrm{ml}$ growth medium in loosely capped $15^{\circ} \mathrm{Oml}$ test-tubes. Incubation was continued at $25^{\circ} \mathrm{C}$ under $16 \mathrm{I} 4 \mathrm{lux}$ of light. Recovered material was subcultured through five passages.

Microscopy. Recovery was determined by haemocytometer counts immediately after rehydrating the material in vials without filter paper or silica gel. Cysts dried on shredded filter paper or silica gel were examined by phase-contrast microscopy. Excystment following rehydration was observed in depression slides on a Leitz inverted microscope, and in wet mounts by phase-contrast microscopy. Phosphate-buffered (pH 6.9) Giemsa stain was added to suspensions of vegetative cells, without prior fixation, to provide a background contrast. One drop of cell suspension was mixed with one drop of stain on a microscope slide and covered with a coverslip: when the edges of the coverslip were sealed with petroleum jelly, the cells remained undistorted for 30 to $40 \mathrm{~min}$.

\section{RESULTS}

\section{Storage and recovery}

The percentage of encysted cells was determined by comparing the number of cysts recovered with the initial number of vegetative cells. There appeared to be no difference in 
Table I. Recovery of Polytomella parva ATCC 2910 and Polytomella caeca ATCC30295 following storage and accelerated viability testing

\begin{tabular}{|c|c|c|c|c|c|c|c|c|c|c|}
\hline \multirow[b]{3}{*}{$\begin{array}{c}\text { Storage } \\
\text { temp. } \\
\left({ }^{\circ} \mathrm{C}\right)\end{array}$} & \multirow[b]{3}{*}{$\begin{array}{c}\text { Storage } \\
\text { time }\end{array}$} & \multirow[b]{3}{*}{$\begin{array}{l}\text { Retrieval } \\
\text { temp. } \\
\left({ }^{\circ} \mathrm{C}\right)\end{array}$} & \multicolumn{6}{|c|}{$\begin{array}{l}\text { Rehydration time (days) before } \\
\text { motile cells were observed }\end{array}$} & \multirow{2}{*}{\multicolumn{2}{|c|}{$\begin{array}{l}\text { Recovery in } \\
\text { vials without } \\
\text { substrate }(\%)\end{array}$}} \\
\hline & & & \multicolumn{3}{|c|}{ ATCCI 2910} & \multicolumn{3}{|c|}{ ATCC 30295} & & \\
\hline & & & $\begin{array}{l}\text { Filter } \\
\text { paper }\end{array}$ & $\begin{array}{l}\text { Silica } \\
\text { gel }\end{array}$ & $\begin{array}{l}\text { No } \\
\text { substrate }\end{array}$ & $\begin{array}{l}\text { Filter } \\
\text { paper }\end{array}$ & $\begin{array}{l}\text { Silica } \\
\text { gel }\end{array}$ & $\begin{array}{l}\text { No } \\
\text { substrate }\end{array}$ & $\begin{array}{l}\text { ATCC } \\
\text { I } 2910\end{array}$ & $\begin{array}{l}\text { ATCC } \\
30295\end{array}$ \\
\hline RT & $\begin{array}{l}\text { None } \\
\text { (control) }\end{array}$ & RT & 2 & 3 & 2 & 2 & 3 & 2 & $18 \cdot 2$ & $17 \cdot 0$ \\
\hline 4 & 7 days & RT $(30 \mathrm{~min})$ & 6 & 3 & 3 & 3 & 3 & 3 & $3 I \cdot 0$ & $32 \cdot 0$ \\
\hline 4 & 7 days & $35(30 \mathrm{~min})$ & 6 & 8 & 4 & 2 & 4 & 3 & $24 \cdot 0$ & 14.0 \\
\hline 4 & 7 days & $60(30 \mathrm{~min})$ & 6 & 3 & NR & 5 & 6 & 3 & 10.6 & $16 \cdot 0$ \\
\hline 4 & 7 days & $100(30 \mathrm{~min})$ & 9 & NR & $\mathrm{NR}$ & NR & 6 & NR & 16.0 & $10 \cdot 0$ \\
\hline-30 & 7 days & RT $(5 \mathrm{~min})$ & 6 & 3 & 4 & 4 & 3 & 3 & $18 \cdot 3$ & $25^{\circ} 0$ \\
\hline-30 & 5 years & RT $(5 \mathrm{~min})$ & 7 & NR & - & - & - & - & - & - \\
\hline-70 & 7 days & $\mathrm{RT}(5 \mathrm{~min})$ & 6 & 3 & 2 & 4 & 2 & 3 & 34.0 & $24 \cdot 0$ \\
\hline-150 & 7 days & RT $(5 \mathrm{~min})$ & 6 & 3 & 4 & 2 & 2 & 3 & 34.0 & $27 \cdot 0$ \\
\hline
\end{tabular}

RT, Room temperature. NR, No recovery.

the degree of encystment between experimental groups (Table I) or between experimental groups and the controls. Distorted, wrinkled cysts were observed under all conditions of storage and were not included in recovery determinations. The mean proportions of cysts recovered were $23.3 \%$ (I0.6 to $34.0 \%$ ) for $P$. parva and $20.6 \%$ (10.0 to $32.0 \%$ ) for $P$. caeca, values which correspond remarkably well to the percentage of cysts spontaneously formed in stock cultures following 6 days of growth $(P$. parva, $20 \cdot 0 \% ; P$. caeca, $24 \cdot 2 \%)$.

Excystment time following rehydration depended on the substrate used for drying the cysts and on the storage conditions. Most rapid recovery resulted from rehydration immediately after drying (Table I), the time for excystment in these control ampoules being delayed only briefly compared with that observed for undried material by Lewis et al. (1974). The substrate had a limited effect on recovery when dried material was not stored. Recovery of material dried on silica gel was delayed by $24 \mathrm{~h}$.

All material stored at $4{ }^{\circ} \mathrm{C}$ was subjected to accelerated storage testing (Table I). Excystment was delayed longer at elevated temperatures. When dried on filter paper, excystment of $P$. parva after exposure to $100{ }^{\circ} \mathrm{C}$ occurred 7 days later than in controls, and $P$. caeca did not excyst. Drying on silica gel produced variable results: after exposure to $100{ }^{\circ} \mathrm{C}$ excystment in $P$. caeca was delayed by 3 days, and $P$. parva did not excyst. Neither species excysted after exposure to $100{ }^{\circ} \mathrm{C}$ when dried in the absence of a substrate. Thus Polytomella cysts may not be stable during long-term storage at $4{ }^{\circ} \mathrm{C}$.

Dried Polytomella cysts were recovered after storage at cryogenic temperatures (Table I) at similar levels to unstored control material. The temperature did not affect the ability to excyst, and both strains were recovered after storage at $-150^{\circ} \mathrm{C}$ for 7 days. Polytomella parva cysts stored for 5 years at $-30^{\circ} \mathrm{C}$ after drying on filter paper were recovered, but those dried on silica gel were not; the percentage recovery was similar to that for cysts stored for short periods of time, and better than that for material exposed to elevated temperatures during accelerated storage testing. 


\section{Microscopic observations}

During counting, complete and incomplete cysts were observed. Incomplete cysts lacked the ectocyst, and starch bodies were dispersed evenly throughout the cell. Complete cysts appeared more typical with closely compact starch bodies, and a thick-walled ectocyst. Both forms were spherical, smooth walled, and approximately Io $\mu \mathrm{m}$ in diameter, conforming to the reported sizes of Polytomella cysts (Pringsheim, I955; Lewis et al., 1974). Both types of cysts could produce viable flagellates. Therefore both were included in recovery determinations.

Cysts dried on filter paper were solitary, and attached to the fibres of the paper. This attachment was not an artefact of observation, since gentle attempts to dislodge the cysts from the filter paper, in wet preparations, were unsuccessful. On silica gel, cysts were aggregated, the number of cysts in one aggregate depending on the size of the silica gel particles. Both solitary cysts and groups were seen in vials containing no substrate.

The morphology and growth characteristics of vegetative cells before and after drying and storage were not noticeably different. Growth curves were typical, reaching the stationary phase in 2 to 3 days. Individual cells demonstrated the characteristic rapid and erratic swimming movements. Numerous starch bodies were present, and sexual fusion was evident.

\section{DISCUSSION}

Polytomella is capable of a high degree of spontaneous cyst formation in liquid culture: up to $80 \%$ during early stationary growth of $P$. caeca (Lewis et al., 1974). Although drying is not imperative for cyst formation in Polytomella, it is conducive to maintaining viability during long-term storage.

The recovery of viable flagellates from cysts stored dried depended on the substrate used for adherence of the cysts. Polytomella caeca excysted within $24 \mathrm{~h}$ following $5 \frac{1}{2}$ months storage on filter paper at $4{ }^{\circ} \mathrm{C}$. Lewis et al. (1973) have reported that spontaneously formed $P$. caeca cysts do not survive more than 6 weeks. Although Polytomella cysts will adhere to glass surfaces and are capable of surviving desiccation in this condition (Pringsheim, 1955), our results demonstrated that they are not likely to remain viable for long. Silica gel is a good drying substrate since it prevents exposure of the stored cysts to humid conditions. However, cysts were not viable after long periods of storage on silica gel. It appears, therefore, that the best substrate so far tested was shredded filter paper. A large surface area is provided which may account for better recovery, as has been shown by Annear (I970). Microscopic examination revealed that cysts were solitary and firmly attached to the filterpaper fibres, whereas large aggregates of cysts were observed on silica-gel particles and in material dried in empty glass vials. Aggregation may prevent complete dehydration, and rehydration, of cysts.

Recovery was estimated by counting all morphologically intact cysts found in the glass vials lacking substrate and expressing the number as a percentage of the number of motile flagellates present before drying. Two distinct cyst types were counted: both were capable of producing viable flagellates. Assuming that all undistorted cysts were capable of excystment, the percentage recoveries did not differ markedly between experimental groups.

Since the number of intact cysts present was not affected by the conditions of storage and retrieval, a second parameter was used to determine viability. The time for excystment to occur was examined following storage and retrieval, and varied widely. This variation appeared to be due to the effects of storage and retrieval, not to selection pressure from the 
environmental extremes. The number of cysts formed in all experimental groups did not differ markedly, and was similar to the number formed spontaneously in broth culture. Sometimes excystment did not occur at all after storage and retrieval, and it appears that delayed excystment depended on the drying substrate, the storage temperature and the length of the storage period.

Accelerated storage testing has been used for predicting the stability of freeze-dried viruses (Greiff \& Rightsel, I965) and bacteria (Mitic et al., 1974). The premise of the test is that at a given storage temperature the viability of dried material declines linearly with time. The decline in viability can be mimicked by short-term studies at elevated temperatures (Greiff \& Rightsel, I965). Accelerated storage testing indicated that if dried Polytomella cysts are stored at $4{ }^{\circ} \mathrm{C}$, viability decreases with storage time. In four of the experimental groups stored at $4{ }^{\circ} \mathrm{C}$, the ability to excyst was completely lost following exposure to $100^{\circ} \mathrm{C}$. However, storage at low temperatures appeared to extend the period of viability (Mitic et $a l$., 1974), and $P$. parva stored for 5 years at $-30{ }^{\circ} \mathrm{C}$, after drying on filter paper, excysted more rapidly than when subjected to accelerated storage at $4{ }^{\circ} \mathrm{C}$. The ability to recover Polytomella cysts following exposure to liquid nitrogen, and subsequent storage at $-150^{\circ} \mathrm{C}$, affords a means of maintaining viable cysts over extremely long periods of time.

Long-term preservation in the encysted state may be applicable to other groups of cystforming protozoons, presently very difficult to preserve. However, cysts must be properly conditioned before exposure to freezing temperatures.

We gratefully acknowledge the excellent technical assistance of John Cozart and John Gray.

\section{REFERENCES}

Alexander, M. T. (1976). Media. In American Type Culture Collection Catalogue of Strains I, I2th edn, pp. 318-368. Edited by H. Hatt. Rockville, Maryland: American Type Culture Collection.

ANNEAR, D. I. (1970). Preservation of microorganisms by drying from the liquid state. In Proceedings of the First International Conference on Culture Collections, pp. 273-279. Edited by H. Iizuka and T. Hasegawa. Tokyo: University of Tokyo Press.

BeERS, C. D. (1937). The viability of ten-year-old Didinium cysts (Infusoria). American Naturalist 7r, 521524.

BURNS, M. E. (1964). Cryobiology as viewed by the microbiologist. Cryobiology 1, 95-102.

Bychenkova, V. N., Lozina-Lozinsky, L. K. \& Namalov, T. (1969). Microscopic observations of the processes of freezing and thawing in Colpoda maupasi. Zoologicheskil zhurnal 48, 1772-1779.

CoRLISS, J. O. \& Esser, S. C. (1974). Comments on the role of the cyst in the life cycle and survival of free-living protozoa. Transactions of the American Microscopical Society 93, 578-593.

Damjanovic, V. \& Radulovic, D. (1968). Predicting the stability of freeze-dried Lactobacillus bifidus by the accelerated storage test. Cryobiology 5, IOI-IO4.

Dawson, J. A. \& Hewetr, D. C. (1931). The longevity of encysted Colpodas. American Naturalist 65, I8I186.

GaRNJOBST, L. (1937). A comparative study of protoplasmic reorganization in two hypotrichous ciliates, Stylonethes sterkii and Euplotes taylori, with special reference to cystment. Archiv für Protistenkunde 89, 317-38I.

GreifF, D. \& Rightsel, W. A. (1965). An accelerated storage test for predicting the stability of suspensions of measles virus dried by sublimation in vacuo. Journal of Immunology 94, 395-400.

Lewis, E., Munger, G., Kiefer, R. \& Wise, D. (1973). Life cycle of Polytomella caeca. In Progress in Protozoology (supplement). Clermont-Ferrand: Université de Clermont.

Lewis, E., Munger, G., Watson, R. \& Wise, D. (1974). Life cycle of Polytomella caeca (Phytomonadida, Polyblepharidae). Journal of Protozoology 21, 647-649.

Mitic, S., Damuanovic, V. \& OtenhaJmer, I. (I969). Procena bioloske stabilnosti liofilizovanih sojeva Str. thermophilus i L. bulgaricus. Prvi Kongres Mikrobiologa Jugoslavije. Zbornik 1021-1028.

Mitic, S., Otenhajmer, I. \& Damjanovic, V. (1974). Predicting the stabilities of freeze-dried suspensions of Lactobacillus acidophilus by the accelerated storage test. Cryobiology II, I I6-I20.

Pringsheim, E. G. (1955). The genus Polytomella. Journal of Protozoology 2, I37-I45. 
Simon, E. M. \& Schneller, M. V. (I973). The preservation of ciliated protozoa at low temperature. Cryobiology 10, $42 \mathrm{I}-426$.

TAYLOR, C. V. \& StRICKLAND, A. G. R. (1935). Some factors in the encystment of Colpoda cucullus. Archiv für Protistenkunde 86, I8I-I90.

TAylor, C. V. \& Strickland, A. G. R. (1936). Effects of high vacua and extreme temperatures on the cysts of Colpoda cucullus. Physiological Zoölogy 9, I 5-26. 